\title{
Divine Intersections:
}

\section{Hindu Ritual and the Incorporation of Religious Others}

\author{
Kathinka Frøystad ${ }^{1}$ \\ Department of Social Anthropology, University of Bergen
}

\begin{abstract}
This article throws the study of multi-religious sociality in Western contexts into relief by examining examples from India. Much of the current scholarship of cosmopolitanism and multiculturalism tends to assume that religious beliefs, practices and spaces make the respective religious communities close in entirely upon themselves. While this assumption may hold true for most of the Western settings we study, it does not necessarily give an accurate description of the conditions for multi-religious sociality in other parts of the world. In India, for instance, religious boundaries still display signs of malleability despite the religious politicization and occasional interreligious violence of the past decades. Drawing on recent anthropological research, this article shows that people of different religious denominations still visit Sufi shrines, that Hindus still incorporate ritual elements and divine beings from the religious traditions of their Others and that they exercise a wide personal choice in terms of spiritual activities, thus enabling spiritual paths that cross in and out of Hinduism. In a Hindu context rituals do not necessarily have an insulating effect; they may also provide points of intersection that open up toward the Other, thus fostering familiarity and recognition. Similar arguments have been made for Buddhist settings. The question is thus whether the current scholarship of cosmopolitanism may entail a certain monotheistic bias that needs to be accounted for, something that is of particular importance when theorizing in ways that make universal claims.
\end{abstract}

Is religion necessarily divisive in societies marked by religious plurality? Much of the contemporary scholarship on cosmopolitanism relies on an implicit assumption that religious boundaries are only crossed within arenas such as popular culture, sports, education, employment and residential spaces, while religious rituals, beliefs and holy places make the respective communities close in upon themselves. Thus hip-hop, football, class rooms, offices, markets and neighbourhoods are scrutinized for their potential to enhance social cohesion across religious boundaries, whereas religious rituals, ontologies and congregational sites are dismissed as unireligious and insulating. Leaving aside ‘dialogues’ in which religious representatives meet to

\footnotetext{
${ }^{1}$ Earlier versions of this essay were presented at the 'Other Cosmopolitanisms' conference at the University of Technology, Sydney, in August 2011 and at the Department of Social Anthropology at the University of Oslo in April 2012. I am indebted to the participants on both occasions as well as to Joel S. Kahn and the anonymous referees of this journal for invaluable comments, many of which would have deserved a far more substantial treatment than I have been able to give them here.
} 
enhance mutual understanding, search for common ground and exercise damage control, religion is typically ruled out as an arena that facilitates inter-religious sociality. This, at least, is the overall impression emanating from studies of cosmopolitanism in Europe, most of which pertain to contexts of recent long-distance migration bringing together members of at least one, and often two, monotheistic religions with long histories of promoting One Truth by sanctioning heresy, blasphemy and apostasy. The dizzying number of government-funded research programmes, conferences, scholarly networks and journals on migration and multiculturalism that have existed in Europe since the early 1990s has reinforced this assumption so profoundly that we have almost witnessed a blind spot in the making. But as this article suggests, religious beliefs, practices and spaces are not necessarily insulating; in some cases they also provide astonishing openings toward religious others.

The potential of such openings was recently suggested in American Grace: How Religion Divides and Unites Us (2010), authored by Robert Putnam and David E. Campbell. Based on data from a large-scale survey throughout the United States, the authors argue that the frequency of religious switching is so high that religion not only fosters 'bonding' ties to coreligionists but also 'bridging' ties to practitioners of other faiths. At least a third of their respondents were married to someone from a different religious community, and a third could virtually see a religious alter in the mirror, so to speak. Additionally, most of their Christian interlocutors - including the most pious ones - thought that non-Christians with good conduct could go to heaven even though the Bible quotes Jesus to have said that 'No man cometh unto the Father, but by me' (2010: 536). To my knowledge this is the first major Western study to take seriously the possibility that religious practices (in this case non-dogmatic interpretations, conversion and lack of sanctions against religious exogamy) can generate 'social glue'. The authors are more preoccupied with the extent to which social capital and trust cross religious boundaries than with religious life as such, and their quantitative method renders unanswerable the difficult question of whether it is religious practices that promote inter-religious ties or vice versa. Nonetheless, their study provides a timely opening for the possibility that certain lay ontologies and onto-practices can encourage interfaith cordiality rather than merely resulting in religious insulation. In this article I want to take this discussion further by introducing some anthropological reflections along these lines from India, where the context of religious plurality is neither one of substantial switching and intermarriage, 
nor one of recent migration, nor even one of Abrahamic monotheistic dominance. What can the study of cosmopolitanism learn from study of the more established religious synthesis on the Indian subcontinent? Drawing on ethnographic observations on how Hindu ritual - or, rather, ritual acts carried out by Hindus - contain ontic 'openings' toward religious others, I argue that these examples provide a crucial counterpoint that needs to be taken into consideration in any attempt to make universal claims about the role of religion in promoting either cohesion or division in plural societies.

In terms of ethnography I describe three of the many religious intersections I observed while doing fieldwork among upper-caste Hindus in the North Indian states of Uttaranchal and Uttar Pradesh: that of a Hindu priest apprentice prostrating in front of the tomb of a Sufi saint, that of a young Hindu opting for a Muslim-style fast rather than a Hindu fast in hope of fulfilling a certain wish, and that of the religious plurality I noted within a single household. It is significant that all these incidents were methodologically serendipitous in the sense that no fieldworking scholar could have planned for them, and that two of the three involved movement rather than spatial fixity and people acting alone rather than in established social units. This is so because uppercaste Hindus do not commit such crossovers particularly often, and because certain kinds of crossovers could even be embarrassing. For years I dismissed these incidents as cases out of the ordinary. But their number kept growing, and whenever I mentioned them to Indian friends or fellow South Asianists, I was told how utterly common they were. Thus despite their singularity and infrequency compared to more conventional forms of upper-caste religious practices, none of the incidents described below is exceptional even after decades of attempts to 'purify' Hinduism and South Asian Islam alike. This is one of the reasons why Joyce Burkhalter Flueckiger, whose work I introduce shortly, wants to 'make more room for the possibility that one basis for shared identity might also be religious' (Flueckiger 2006: 171, emphasis in original). And if this can be said about the most religiously plural and populous country in the world, there is due reason to rethink the models that inform the current scholarship of cosmopolitanism in multi-religious societies, asking to what extent it may entail an implicit Western, monotheist bias. As Don Handelman (2008) argues in a discussion on the concept of belief in social anthropology, graded, organic ontologies of the kind found in Buddhism incorporate new elements far more easily than monotheist religions. This is so because the former acknowledge a continuum of divinity between 
gods and humans while the latter subscribe to a more 'fixed' cosmic order given their anchoring in the Fall from Paradise which separated humans from God. ${ }^{2}$ Following this argument, organic ontologies are typically more elastic and enable more religious intersections that hold potential to unsettle the difference which supposedly is the primary factor that distinguishes religious communities from one another. The Hindu context in which I work shares this elasticity, as the next section suggests.

\section{Historical and Analytical Background}

Indian historiography is replete with descriptions of indeterminate religious boundaries, ontological overlaps and interfaith cordiality alongside studies of conquest, missionizing and strife. It could hardly be otherwise with such a variety of local cults, rhizomatic offshoots from the so-called 'great traditions' and influence from immigrant traders and rulers throughout the last millennium. The popularity of Sufi pirs (Islamicite guru-like healers) and the dargahs (shrines) constructed around their tombs has received particular attention given their mediation between Indic and Islamicite traditions. ${ }^{3}$ Originally Muslim mystics who were 'enrolled' among the Hindu seers (Mohammad Habib, in Alam 2006: 21), many pirs came to incorporate Indic elements. Their followers, clients and adepts were drawn from a variety of communities, though typically from castes of low or middle rank. The songs and stories that narrated their deeds could either emphasize their 'Hindu' or 'Muslim' traits depending on the composer and performers that helped keep the tradition alive. Over time their dargahs could either be 'Hinduized' or 'Islamicized' depending on the religious outlook of the political rulers in the area, which occasionally turned dargahs into spaces of fierce political dispute (Hayden 2002).

Despite the growing crystallization and politicization of religious identities since the nineteenth century, not least during the Hindu nationalist wave in the early 1990s (Hansen 1999), contemporary dargahs still have profound mediating qualities. Carolyn Heitmeyer (2011), for instance, describes a dargah in the Gujarati town of Mahemdabad that, alongside a portrait of its

\footnotetext{
${ }^{2}$ Handelman's observation is probably more appropriate for Protestantism and Judaism than for Catholicism and Islam.

${ }^{3}$ I follow Gilmartin and Lawrence (2002) in trying to escape the historical inaccuracy of projecting the 'Hindu' and 'Muslim' terms back onto a distant historical past by using the terms 'Indic' and 'Islamicite' to distinguish between autochthonous traditions on the one hand, and traditions that entered the Indian subcontinent with Muslim traders and rulers on the other.
} 
founding pir and his successors displays a portrait of the mainly Hindu saint Sai Baba of Shirdi besides being decorated with the Hindu mantra 'Om' alongside the crescent moon and holy words from the Quran. Parvis Ghassem-Fachandi (2011) describes another dargah in Gujarat whose trustees always encourage its visitors to enter the Hindu Ram temple across the courtyard before they leave the village. And Joyce Burkhalter Flueckiger describes how a female Muslim healer and pir husband in Hyderabad freely let their disciple invoke Hanuman, the monkey god in the Ramayana epic, on their premises. For them Hanuman was a messenger who could bring requests to the saint Suleman Baba, who in turn was renowned for retrieving lost objects (2006: 178). Hindu deities were by no means rejected as phantasms but rather acknowledged as beings who were indisputably powerful despite being subordinate to Allah and his archangels and saints. All these studies describe the clientele as interreligious, working class and low- or middle-caste. To Indians and South Asianists the implicit assumption that religious rituals, practices and spaces necessarily are insulating would simply come across as badly informed.

A few studies of divine intersections in India have also moved beyond Sufi pirs and dargahs. Jackie Assayag's monograph At the confluence of two rivers (2004, first published in French in 1995) is a seminal contribution in this regard. By following the religious life of Hindu, Muslim and Christian villagers in Karnataka for more than a year, Assayag gives a convincing account of the festivals, rituals and spaces that separated the communities one from another, and of those that brought them together. The dargahs had clearly the strongest centripetal effects, but Assayag also documents the continued participation of Hindus in the Shi'i Muharram processions despite the falling Hindu attendance elsewhere in the country, to name one of his valuable observations. Based on a more individual methodological approach, Veena Das (2012) narrates the story of a Muslim healer ( $a m i l$ ) in Delhi whose occult powers partly derived from the rituals he was made to perform in an abandoned Kali temple in the Pakistani province of Sindh. Towards the end of his apprenticeship as an amil he was brought to this temple where a luminous person whom his companion addressed as Guru Maharaj seated them in front of an image of the Hindu goddess Kali and guided them through some rituals he did not understand, but which helped him gain control of a female spirit that had troubled his family since his grandfathers' days. Eager to live up to the ideal of Islamic purity, however, the amil was deeply troubled by the Hindu elements of his powers. Guru Maharaj had begun to appear in his dreams, and when Das met him, he 
consulted Islamic manuals on dreams to find out whether his dreams about the mystic in the Kali temple could have been sent by Shaitan. Religious identities, Das concludes, can still be surprisingly malleable.

In my attempt to continue the examination of contemporary divine intersections in India I am particularly influenced by three analytical prisms. One emerges from Flueckiger's aforementioned study of the female Muslim healer in Hyderabad. Lovingly called Amma (mother) by her clients, her healing room was a ritual space in which Muslim, Hindu and Christian clients arrived in search for spiritual assistance for their problems. Lack of space made the clients sit side by side and listen to each others' stories, whether they pertained to chronic pain, sickly children or disobedient wives. Regardless of their religious background, they all worried that their problems could have been caused by the evil eye, black magic or malevolent spirits, hoping that Amma could diagnose them correctly and advise a proper cure. In this way Amma's healing room emerged as a caurasta (crossroads) where people of different denominations met and ontologies intersected to such an extent that religious boundaries became overwhelmingly fluid. What counted was ritual efficacy, not fixed identities or 'official' religious beliefs (see Lindquist 2008 for a similar argument).

Another useful prism is Michael Carrithers’ polytropy concept (2000), which aims to capture the common Indian tendency to seek spiritual intervention from many (poly) directions (tropos). This prism originates in Carrithers' long-term study of Digambar Jains, a religious community that does not acknowledge God in a dualist form (i.e. as something external to oneself), but whose lay practitioners nevertheless perform Hindu-style worship (puja) to the 24 realised Jain beings (tirthankars) as if they were Hindu deities. Some also worship Hanuman. In Carrithers’ interpretation such slippages occur because the physical movement of minimal puja - particularly the pranam or namaskar greeting of joining one’s palms while bowing - is so deeply engrained that lay Jains do it as a bodily reflex to everything that 'seems holy' (cf. Carrithers, et al. 2010). ${ }^{4}$ The result is a constant tension between 'purists' (who subscribe to an official version of the religion) and polytropists. As Carrithers points out, polytropic tendencies are equally common

\footnotetext{
${ }^{4}$ I am not entirely convinced by Carrithers' 2010 argument that the propensity to do puja to everything that 'looks holy' is unrelated to vernacular ontologies, but more detailed discussion of this argument will have to await a later occasion.
} 
among Hindus and Jains, with the crucial qualification that the quest for Hindu purity is also driven by religious reform movements and Hindu nationalist organizations that add a considerable political thrust.

A third prism I find useful is Louis Dumont's ‘encompassment of the contrary’ principle. Originally developed to capture the hierarchical thought that underpins caste (1970), Dumont defines 'hierarchy' as distinct from 'rank' in that it subsumes, or encompasses, that which it dominates, making it a lesser part of itself. Given a hierarchical relation between X and Y, X stands for the whole and $\mathrm{Y}$ for an imperfect derivative. His notion of encompassment is applicable far beyond caste: Dumont's own examples include the relation between Adam and Eve in the Bible, between goods and work in classical political economy, between work and exchange for Adam Smith and between production and consumption for Karl Marx (Dumont 1970:245), and further examples are found in Rio and Smedal (2009). Following Dumont one may discern how religious elements that 'officially' belong to a different religious tradition are incorporated and simultaneously subordinated, as in Amma's incorporation of Hanuman among the Islamic messengers. Elements that are contrary to a purist may nevertheless be incorporated in ritual practice, especially in 'caurastic' spaces.

As a more general prism I nevertheless prefer to speak of 'divine intersections', which I use as common denominator for all the forms of religious synthesis one may encounter in plural religious societies. Advocating one principle as more fundamental than the others would be to misinterpret their complementary nature, though it is true that one principle may dominate the others in singular cases. Let me now detail three of the divine intersections I have observed in upper-caste ritual life over the years while conducting fieldwork on everyday Hindu nationalism and new spiritual trends respectively. I begin by following the well-trodden path of looking at dargahs, albeit in an unconventional way.

\section{The Priest Student and the Pir}

Haridwar, February 2011. The sun was losing its midday intensity, and one by one the elderly ashram residents left their rooms for an evening stroll or a cup of tea in the pale sun. The ashram, a residential spiritual centre I call Joyti Ashram, was located at the end of the road, bordering the 
holy Ganga river to the East, a tributary river to the North, a ramshackle low-caste settlement (basti) to the West and a brick-house village inhabited by middle-caste farmers and traders to the South. Some years earlier I had lived in this ashram to study the appropriation of Western New Age influences among its mainly urban middle-class Hindu residents, and now I had returned for a follow-up visit. Noting continuities and changes, I registered that the tributary had been reduced to a tiny stream that could now be crossed more easily, and that the morning and evening arati (fire worship) rituals in the ashram temple now longer was conducted by a professional priest but by a group of twelve advanced students at a nearby Vedic college in exchange for free accommodation. As it turned out, these changes were vital for the incident that was to unfold that afternoon.

Before moving on, some contextual details are required. Haridwar, the closest town, is one of India's main Hindu pilgrim centres. Tourist brochures state that this is where Lord Vishnu's heavenly bird Garuda spilled his elixir of immortality, where the renowned Kumbh Mela festival is held every twelfth year, where one's misdeeds can be cleared in the Ganga to fasten the way to liberation from rebirth (moksha), where scores of family genealogies are stored and where the density of temples, ashrams and pilgrim rest houses (dharamshalas) surpasses that of any other city except, perhaps, Banaras. While downtown Haridwar is almost uniquely Hindu, the nearby towns have a sizeable Muslim minority, the administrative unit of Haridwar District counting no less than 34\% Muslims (Census of India 2011). Local newspapers describe the interreligious relations in the district as cordial, also during religious turbulence elsewhere in the country, as when Hindu-Muslim riots raged in 1992 and 2002. The rural surroundings of the Joyti Ashram was nevertheless almost uniquely Hindu except for two unassuming dargahs. One was located within a partial enclosure along the village road; the other in a forest clearing across the diminished tributary, and this is the dargah that became the scene for the present ethnographic case.

Writing field notes by the window I had often seen this dargah from a distance. Deserted during daytime but with occasional flickering lights at night, the pir still had his devotees. Once I also heard singing, which indicates a gathering to mark his death anniversary, his wedding to Allah (urs). Until this particular day I had refrained from visiting the dargah due to the reproaches I 
often got from the ashram residents if I strayed too far away from the roads and spaces they held to be safe and non-defiling. The forest across the tributary had not only been difficult to access but also potentially dangerous given that village outskirts, forest areas and places where rivers meet are places where evil spirits and restless ghosts (bhut-pret) are known to hover about (cf. Assayag 2004: 101). Visiting a place associated with death could moreover be seriously defiling. No longer so restricted by such concerns now that my main fieldwork was over, I decided to walk across. To make my expedition transparent I made it a point to inform the ashram manager, who surprised me by asking if he could come along. To my even greater surprise, one of the priest students joined us as well. So off we went, across the drying-out river basin and up along the path toward the forest clearing - the priest student first, the manager next and then me.

Once there I noticed that the space was larger than I had thought. It contained not only one but two dargahs; a large one in the centre and a smaller one to the left. There was nobody there but us. All we could hear was the sound of the river and the whispering of trees. The young men approached the place in silence. Before entering the stone enclosure they reached for their shoes. 'Here we must take off our shoes’ (yahan chappal utarna hai), the priest whispered. Having entered the makeshift portal, they stood respectfully in front of the central dargah, joining palms just as they did in the temple. To my surprise the priest student then knelt down in front of the central grave and bowed his head to the ground. Next he proceeded to the smaller tomb, where he bowed respectfully with his palms together. The manager followed suit but remained standing, presumably to avoid soiling his light grey trousers. The priest student, wearing dark track pants, had no such concerns. On the way back I was full of questions. Had they been there before? The priest student once, the manager never. Whose dargahs were they? No idea, probably some pir baba or the other. ${ }^{5}$ Who maintained the space and came for urs? Maybe someone from the nearby basti, who were only 'half Hindus'. As we approached the ashram we could hear the sound of hymns (bhajans) that were always played over the loudspeakers prior to the aratis. The priest student sped up, and as soon as we returned he rushed to his dormitory, had a quick bath, changed into his white priestly garb and joined his fellow students in ringing the bells to alert the gods to the Vedic chanting and fire sacrifice that were to follow, switching within less than an hour from

\footnotetext{
${ }^{5}$ Baba is a respectful title typically given to pirs, gurus and other men of renown.
} 
prostrating to an unknown Muslim pir to worshipping Ganesha, Krishna, Radha, Ram, Sita, Hanuman, Shiva and Durga, to name the main deities represented in the temple.

How come a Hindu priest student paid such deep respect to an unknown pir? That Hindus seek polytropic help from pirs - whether living or in their graves - is not uncommon. Pirs are renowned for their remedies against long-term chronic problems such as infertility, weak children, madness, marital distress and repeated economic loss, especially if suspected to be caused by supernatural beings (cf. Flueckiger 2006). Whether the beings are called jinns (as in vernacular Islam), asuras (as in Hinduism) or something else is insignificant, which is why pirs and dargahs attract Hindu and Muslim clients alike. Pirs are considered experts in diagnosing spirit afflictions, whether by means of Islamic geomancy or other divination forms. They also treat these afflictions - most commonly by writing numbers or words on slips of paper that are to be worn, burned, hidden or smoked. In serious cases the pir can also contain spirits by transferring them from the patient to an object. A renowned pir has an immense innate power (barkat/baraka), which survives his passing. The tomb of a renowned pir thus radiates an immense protective power, which is why his adepts and clients construct a shrine around it and convert it into a place of healing and solace. Though this particular dargah on the outskirts of Haridwar was modest, its location suggested a pir capable of treating highly serious afflictions. Even an outsider unexposed to village lore would grasp the immense power present in this forest clearing as long as he acknowledged the existence of malevolent spirits and a pir's ability to contain them. Clearly the priest student did so since he was the one to lead the way and instruct us how to behave.

That being said, it is rare that Hindus of Brahmin descent consult pirs and dargahs, especially if they are priests. Not only should their Vedic rituals ideally contain all the remedies required; Brahmins are also more resistant against spirit attack than low castes since their bodies generally are better sealed. According to Osella and Osella (1999), malevolent spirits typically enter human bodies through their lower orifices (the anus, the vagina and possibly the navel), and the many ritual prescriptions and sealing practices that Brahmins typically do make them virtually impenetrable. Yet even Brahman priests are known to have secretly consulted pirs and dargahs as 
a last resort. ${ }^{6}$ In the incident described above there was no need for assistance, but the deep prostration of the priest student nevertheless suggests a strong appreciation of the barkat of the place, prior acquaintance with pir healing and acknowledgement of the possibility that his body could be insufficiently closed since he had neither grown up in a priestly household nor completed his Vedic education yet. In terms of analysis the incident may be described as a transition from purism to polytropy and back following the physical movement from a Vedic space to a 'caurastic space' and back. While the condescending remark about the basti villagers being only 'half Hindu' appears to boomerang on himself, it primarily reflects the tension between these modes that he experienced midway back to Vedic purity, as if deliberately shaking off his own polytropic inclinations. Above all, this incident demonstrates that even Brahmins may have considerable ontic overlaps with vernacular Islam, which makes the Muslim Other less unfamiliar than he or she would otherwise have been. To deepen this point I turn now to a ritual act that crossed the Hindu-Muslim divide in an entirely different way.

\section{Ratan's Roza}

Kanpur, January 1993. Like several other cities in North India, Kanpur was about to recover from the gravest Hindu-Muslim riots India had experienced since the secession of Pakistan in 1947. Only a month earlier around 110 people had been killed in this post-industrial city in retaliation for Muslim protests against the demolition of the Babar mosque in Ayodhya a little further east. Streets that had been deserted for weeks due to curfew and fear were now returning to life. It was in this context (elaborated in Frøystad 2005, 2009) I first met Ratan, a 19-year old college student whom I engaged one week later as a research assistant. His task was to help me conduct a survey among working-class Hindus in the outskirts of town to assess the degree to which they shared the negative views about the 20.4\%-strong Muslim minority in the city that I had found in the middle-class segment. In the months that followed Ratan and I spent substantial time together knocking on doors, filling forms and sipping tea with our respondents, which is how I came to know about his roza (fast).

Ratan was a Khatri, a caste that claims descent from the Kshatriya (warrior/king) varna in the Vedic hierarchy, from the region of Punjab and - according to some - from Surya, the sun god.

\footnotetext{
${ }^{6}$ Ute Hüsken, personal communication.
} 
Living with his parents, younger brother and two servants in a bungalow reserved for civil servants, Ratan was privileged compared to his average age mate. He had just begun his BA studies, and his evening assignment for me gave him a welcome opportunity to earn pocket money while getting acquainted with the most outlandish foreigner in town. One day Ratan surprised me by rejecting the tea and sweets we were routinely offered by our respondents. He did not even want water in the breaks. Worrying that our interlocutors would be offended by his rejection of their hospitality, I pleaded with Ratan to have at least one sip of tea in each house, but to no avail. This gave him no option but to let me in on his secret love affair.

As it turned out, Ratan was in love with a girl in his class, and she with him. In 1993 Kanpur was still a city in which virtually all marriages were arranged, pre-marital relationships were scandalous and youngsters of the opposite sex could not be alone together without damaging their reputation. As it turned out, Ratan's parents were going away for the weekend and Ratan had concocted the following plan. He would dismiss the servants and smuggle the girl home on a cycle rickshaw, covered in a brown woollen shawl that made her resemble an elderly woman to potential gossipmongers in the neighbourhood. Safely inside they would share his food, chat and perhaps even hold hands and kiss. But could he succeed without getting caught? Ratan was nervous. Nothing should go wrong. To optimise his chances, Ratan decided to undertake a oneday roza. Roza is the Persian term used by South Asian Muslims to designate the fasting prescribed by Islamic law during the month of Ramadan. Some Muslims also fast at other times for a particular wish to be fulfilled, and this was the kind of fasting for which Ratan had opted.

Why did a young Hindu select a Muslim ritual of wish-fulfilment despite its Hindu equivalents? Let us consider the alternatives. One was vrat, a Hindu fast typically maintained during religious festivals or independently as a pledge. Yet a vrat would be too feeble a stratagem for such a risky plan. The working logic appeared to be that, other things being equal, the degree of efficacy was proportional to the degree of sacrifice, and since a Hindu vrat only required abstention from certain kinds of food while an Islamic roza prohibited not only food and drink but also the swallowing of one's own saliva, a roza would be more potent. ${ }^{7}$ Besides, vrats are primarily done

\footnotetext{
${ }^{7}$ Ratan took the saliva prohibition very seriously, which - given his inexperience - resulted in considerable spitting outside our interviewees' homes. Fearing that this would add to their offence, I had to end our working day far earlier than usual.
} 
by women and have far more pious purposes, such as expressing devotion to God, ensuring the longevity of one's husband or lifting a curse (Lipner 1994: 261), which made vrat entirely inappropriate, if not counterproductive in Ratan's case. Following the same logic, another alternative could have been to seek help from a Hindu deity by a more elaborate puja offering than usual. Yet pujas are ideally conducted to ensure the general wellbeing of one's family and wider community, not for individual wish-fulfilment that would defy their propriety (Fuller 1992:69-72). This made puja equally inappropriate as a vrat, so if Ratan was to seek divine help, he had to look beyond the ritual repertoire with which he was familiar. A Hindu option could have been to seek help from a tantric, but tantrics were hard to find and time was short. Doing roza - which he knew about from Muslim classmates - was at once quicker, more potent and more discreet. That none of his Muslim classmates were likely to have done roza for such a dubious purpose did not appear to trouble him. Whether he was unaware of its inappropriateness or reckoned that potential adverse effects would be milder since he generally relied less upon the grace of Allah than on the Hindu deities favoured by his family is however uncertain.

Interestingly Ratan had no hesitation in crossing the religious boundary in search for divine assistance despite the intense politicization of Hindu-Muslim relations of the preceding months and years. As such he exemplified the polytropic principle in a slightly different way than that indicated by Carrithers: rather than joining his palms in an 'unofficial' direction, he made a different bodily sacrifice from the usual. For this to make sense, Ratan must have acknowledged the efficacy of certain Islamic rituals. The extent to which he acknowledged Allah and his powers as well is less clear, but if he did, there are two ontological possibilities. Either he considered Allah another name for Brahman, the Absolute, which is not uncommon among Hindus, or alternatively he saw Allah as a deity with highly specialized powers but insufficiently important to merit regular attention. The latter possibility would invert the way in which Flueckiger's female healer incorporated Hanuman though both cases would bear strong resemblance to Dumont's principle of encompassment in the sense that they subsumed their contraries without altering their own logical systems. Incorporations of this kind are particularly common in Hinduism, which has often been likened to a sponge (see Inden 2000, Smith 2003 for a critical discussion of this argument). For another incorporating aspect of Hinduism I now move to my final case, which examines the element of personal preference. 


\section{The Multispiritual Soundscape and Personal Preferences}

Kanpur, March 2011, late morning. Having finished our tea, those in my host family who had not rushed off to work withdrew one by one to have a bath, get dressed and do their morning rituals. Eyeing the possibility of an hour's solitary fieldnote writing, I grabbed my laptop and began to type. Half an hour into my work the sound of loud female chanting - nam myo renge kyo, nam myo renge kyo, nam myo renge kyo - began to emanate from my host's brother's section of the house. The sound came from the Soka Gakkai group of his daughter-in-law, which gathered twice a week for collective chanting. Five minutes later a male, monotonous recitation joined it from the opposite side of the house. Jay Hanuman gyan gun sagar...the voice began. This was my host, the retired pater familias, who had begun his daily recital of the Hanuman Chalisa. On top of this unintended duet a ting ting ting sound suddenly penetrated the air. This was the temple bell with which the latter's daughter-in-law alerted the deities in the house temple to the daily puja she was about to begin. Thus within a single home one could hear a multispiritual soundscape representing no less than three modes of worship and two world religions. And this was just the auditory aspect of the religious diversity in the family.

As most other Hindus in this region, this family subscribed to a vernacular, dualist form of Hinduism that acknowledged wide array of gods and goddesses of different abstractions. An annual and weekly cycle of worship ensured that each of the main deities received their due share of attention, making sure that none of them felt abandoned and took revenge by causing misfortune. Beyond these cycles there was a considerable element of personal choice. According to the kuldevta principle, each family, lineage or caste may have a patron deity who is accorded a prominent ritual position. Additionally, the ishtadevta principle enables each family member to devote particular attention to a deity of his or her choice. What I want to suggest is that the ishtadevta principle reflects the possibility of a far wider personal choice - not only of patron deity, but also of mode of worship, sect, movement, guru and so on, which in turn enables personal spiritual biographies that sometimes venture outside what is generally acknowledged as 'Hindu'. ${ }^{8}$ Those who undertake such spiritual paths may in turn bring some of their new spiritual

\footnotetext{
${ }^{8}$ Ventures out of Hinduism are generally temporary and partial, but can also form the seed of permanent conversion, as Flueckiger (2006) shows in her description of a Hindu apprentice of Amma who, after several years, changed his name and underwent circumcision to become a Muslim.
} 
elements home, which, though not always inspiring their relatives to follow suit, at least produces a certain familiarity, which resonates with Putnam's and Campbell's argument from the US.

Returning to the aforementioned family - an upper-caste family of Punjabi descent living in an old bungalow in the city of Kanpur - its diversity of worship can be summarized as follows. Their life cycle rituals and the main annual festivals were officiated by a professional Brahmin priest who had conducted its Vedic rites for several decades. The pater familias had Hanuman as his ishtadevta. Every morning since his wife passed away he recited the Hanuman Chalisa, a devotional poem about Hanuman composed in the sixteenth century. On occasional Tuesdays he also visited the neighbourhood Hanuman temple. His sons limited their ritual participation to the annual festivals, but the wife of the eldest one had cleaned out a closet in order to install a house temple (mandir) where she could worship Durga, Shiva, Hanuman, Ganesha and Krishna as well as a few minor deities. Her temple images also included a representation of Guru Nanak, the founder of Sikhism, to whom she did puja just like she did to the aforementioned gods. Many Hindus have high reverence for Guru Nanak, but since iconolotary and idol worship (murti puja) were among the key factors that made Sikhism crystallize as a separate religion (Mandair 2005:273), doing puja to Guru Nanak seems to be a double contradiction at first sight. Making such an argument would however be to value theological principles over ritual, consistency over bricolage, beliefs over practices, ontologies over ontopraxis, and purity over polytropy. Following Carrithers (2000), the propensity of doing puja to everything that 'seems holy' - in this case Guru Nanak - overwrote completely the potential logical inconsistency of doing so. Indeed, my host's daughter-in-law freely incorporated Guru Nanak among the deities she worshipped just like Amma incorporated Hanuman, thus making the turbaned Guru Nanak a highly familiar character for her four-year old son, his cousins and playmates. In this way the young mother brought Sikhism to the house, albeit in an altered form.

Moving on to a shelf with religious paraphernalia displayed out of respect rather than for worship, I found additional surprising incorporations. Next to a marble Shiva lingam, a dusty image of Ganesha, an image of the nineteenth century saint Shirdi Sai Baba and a photograph of the deceased guru of a family friend was a crucifix of Jesus Christ with the letters INRI written on the upper part of the cross. The incorporation of Jesus is interesting. Contrary to the common 
argument that contemporary Hinduism was modernised in a protestant fashion to better withstand competition from the religion of the colonizers, what we rather see in contemporary micro settings is that Hinduism incorporates Christianity in an encompassing manner. Placing a crucifix on a shelf or in a house temple alongside Hindu deities is only one way in which this may occur. Another is by means of the legend that Jesus, rather dying on the cross, managed to escape to Kashmir, where he became a famous yogi. A shrine in Srinagar marks what its adherents take to be his tomb. A third mode is found in the legend that portrays Jesus as an incarnation of Vishnu, almost on par with Krishna. While the forms of incorporation differ, the principle remains that of encompassment, subordination and transformation. Though my host once claimed to only keep the crucifix there in fond memory of the priest from his Catholic school, he also expressed a desire to safeguard himself by 'covering' as many divine beings as possible in his ritual invocations, which also made him include Jesus in the all-round invocation that followed his Hanuman Calisa recital.

The religious diversity was even more remarkable in the portion of the house in which his brother's family lived. His wife - whom he had defied his parents to marry - was born in a Parsi family and still identified as a Zoroastrian, still participating in numerous Zoroastrian religious functions with her natal family. In her present home it was nonetheless she who performed all the domestic Hindu rituals that did not require a professional priest. Their son followed his cousins in restricting his worship to the main annual rituals, but his wife had become an active follower of the Japanese Soka Gakkai movement, which spread like a wildfire among middle-class housewives in North India in the 2000s. Twice a week her group got together to chant the Japanese title of the Lotus Sutra (nam myo renge kyo) for thirty minutes to awaken their Buddha nature, a practice initiated by the thirteenth-century Buddhist monk Nichiren Daishonin and now promoted by the Indian branch of the Soka Gakkai Movement. On holidays their husbands and children occasionally joined in, and the nine-year old son in this particular family had been enrolled in a Soka Gakkai youth programme. Yet none of this precluded the family from selfidentifying as Hindu, which was what they had asked the Census officer to tick off when he came to collect data for the Census of India 2011. 
Summing up, the extraordinary religious diversity within this semi-joint family included images and elements from mainstream Hinduism, Sikhism, Christianity, Zoroastrianism as well as Buddhism. Of the world religions represented in this part of India, the only religion missing was Islam. This void was not necessarily a token of sharper religious alterity; it could equally well be a sign of respect. Having Islamic representations in the house temple would presumably be interpreted as denigrating by Muslim visitors given the strict Islamic prohibition of idol worship. And though the family technically could have had Qu'ranic calligraphy or an image of Kaaba on the wall, they had no way of predicting how Muslim visitors would have appreciated such images decorating the house of non-believers (kafirs). The best friends of the sons happened to be Muslim, and they were far too precious to be alienated. The religious distance that this family maintained to Islam could thus equally well be analysed as a precondition for maintaining cordial relations with these and other Muslims. If so, it would pose an interesting twist to Putnam and Campbell's conclusion that religion may foster bridging as well as bonding ties: in this case preexisting bridging ties rather precluded religious crossover by respecting certain Islamic exclusivities. Beyond Islam, though, the home of my host was virtually a religious caurasta (crossroads) in itself.

\section{Concluding Remarks}

Let me wrap up by reiterating the main points of the Russian Dolls-like argument of the preceding pages, beginning with the outer layer. Religious practices, beliefs and rituals do not necessarily insulate religious communities from one another; they may also provide ontic openings that make religious alters more familiar. Religious traditions do not necessarily have as hard kernels as they do in the monotheist contexts that underpin most current reflections on cosmopolitanism, something we ought to take into account if we aspire to develop analytical models with broader applicability. The main lesson from India is that everyday religion is still replete with 'divine intersections' that constitute a subtle, under-theorized counterforce against religious and political discourses of purity despite their inability to eradicate either. A deeper problematization of the scarcity of such a counterforce in Western contexts would be one way to bring the study of cosmopolitanism forward in a manner that incidentally also falls in line with Chakrabarty’s call (2000) for the ‘provincialization’ of Europe. In order to make these arguments I have been inspired by the budding 'ontological turn' in the anthropology of South Asia, which 
privileges everyday ontic practices over religious texts, political rhetoric and patterns of social action. For the purpose of this essay I have found particularly useful Flueckiger's crossroads (caurasta) concept (2006), Carrithers’ purity-polytropy distinction (2000) as well as Dumont's classic encompassment of the contrary model (1970), to which I have added the ishtadevtarelated Hindu emphasis on personal choice. The extent to which these lenses hold relevance for potential intersections elsewhere is a question I must leave for others; my main hope is to inspire further research along these lines.

Arguing that religious rituals are not necessarily divisive is not to argue that divine intersections across religious traditions are never divisive. Indeed, certain divine intersections amplify conflicts, particularly if religious boundaries coincide with stark socio-economic differences. Diane Mines (2007, 2002), for instance, describes how a Scheduled Caste man entering a temple to worship the village goddess against the will of its upper-caste trustees triggered a conflict that ended with murder despite the legal prohibition against denying temple entry on the grounds of caste. The trustees did certainly not appreciate the low-caste appropriation of their goddess and ritual space but rather considered it an unpardonable transgression. Harrison (1999) mentions additional examples, including that of Sinhala Buddhists in Sri Lanka who besides appropriating the Tamil minority's worship of Kataragama also sought to deny the Hindu origin of this worship (cf. Gombrich \& Obeyesekere 1988). He also brings up the wounded feelings of many Native Americans over the New Age appropriation of their shamanic rituals, which constituted an inalienable part of their identity (see Aldred 2000). Once our analyses shift to contexts of starkly unequal power relations and emphasize the perspective of the 'appropriated' and their spokesmen rather than that of the 'appropriators', it becomes evident that not all divine intersections are favourable for societal cohesion. Yet in the Indian cases discussed in this paper, there was no sign of hurt or loss, though there would undoubtedly have been so if the picture of Guru Nanak had been replaced by a picture of the Kaaba, let alone of the Prophet. Divine intersections that challenge religious prohibitions are unlikely to have cohesive potential.

Two questions require further attention. The first is Putnam and Campbell's unanswered puzzle of whether it is religious practices that promote interreligious ties or vice versa. My own cases may at first sight seem equally indeterminate: while the roza and the crucifix display were 
anchored in pre-existing interreligious ties, the reverence for Guru Nanak and Soka Gakkai-style Buddhism were not. Based on my field experience so far I suggest a sequence of action in which a pre-existing interreligious tie - often of the kind that Granovetter (1973) analysed as 'weak' may well provide the initial ritual inspiration, the resultant ontological opening of which in turn may pave the way for additional interreligious ties. Whatever the context-specific answer may be, it must be sought by a close attention to process rather than in abstract ideas of causation. Another question that requires more attention is whether our eagerness to promote interreligious cohesion inadvertently leads us to overemphasize the frequency and beneficial effects of ontological openings. Social anthropologists have often debated the influence of their moral positioning on their research, and as Roy D'Andrade (1995) argues, 'moral models' which are too strong can easily make us overlook crucial contrary evidence. While I largely agree with his warning, it must also be said that the current interest in ontological meeting points - within or beyond India - partly arose to counterbalance the long-standing academic attention to religious purity as expressed in religious texts, nationalist rhetoric and interreligious conflict. To document their subtle counterforces, fieldworking scholars have a crucial role to play, though this does not entirely solve the 'moral models' problem.

I end with a speculation that may clarify my own moral entanglement while bringing the question of divine intersections westward to my home country, Norway. Could the massive rhetoric against European Muslims and Islam that has increasingly dominated social media and sections of the press since the mid 2000s have been reduced if the religious traditions in the country $79 \%$ are members of the Lutheran State Church, 2-3\% of various Muslim congregations - had been more open to ritual crossovers? Personally I believe so. Most of the anti-Islamic rhetoric reveals a striking lack of knowledge about Islamic beliefs and practices though it increasingly has come to revolve around Islam - in stark contrast to the Hindu nationalist anti-Muslim rhetoric in India, which primarily revolved around non-religious issues (cf. Frøystad 2005). Interestingly it took a ghastly massacre to bring about the first known ritual intersection between Christianity and Islam in Norway. In July 2011 the blond 32-year old Anders Behring Breivik killed 69 participants of the annual Labour Party youth camp whom he held co-responsible for what he took to be an 'Islamization' of Norway. One of the victims was the 18-year old Bano Abobakar Rashid whose family had fled from Kurdistan in 1996. Hers was the first funeral after the 
massacre, and her parents' decision to organize a Christian-Islamic burial - widely covered in the press - was not only invented to reflect the religious traditions that had influenced their daughter but also to communicate to the Norwegian public that the mutual exclusivity of Islam and Christianity had been widely exaggerated. The fact that it took such a disastrous event for a ritual intersection to come about speaks volumes about the nature of religion in Northern Europe. Fortunately it says less about the prospects of multireligious sociality elsewhere in the world.

\section{References}

Alam, S. 2006, 'On retelling the Muslim conquest of North India', in Chatterjee, P. \& Ghosh, A. (eds), History and the Present, Anthem Press, London, pp. 24-43.

Aldred, L. 2000, 'Plastic shamans and Astroturf sun dances: New Age commercialization of Native American spirituality’, American Indian Quarterly, vol. 24, no. 3, pp. 329-352.

Assayag, J. 2004, At the Confluence of Two Rivers: Hindus and Muslims in India, Manohar, New Delhi.

Carrithers, M. 2000, 'On polytropy: Or the natural condition of spiritual cosmopolitanism in India: The Digambar Jain case’, Modern Asian Studies, vol. 34, no. 4, pp. 831-861.

Carrithers, M., Candea, M., Sykes, K. \& Holbraad, M. 2010, 'Ontology is just another word for culture (Debates in Anthropological Theory, University of Manchester, 2008)’, Critique of Anthropology, vol. 30, no. 2, pp. 152-200.

Census of India 2011, Basic Data Sheet, District Haridwar 813, Uttaranchal (05), http://www.censusindia.gov.in/Tables_Published/Basic_Data_Sheet.aspx accessed 15 March 2012.

Chakrabarty, D. 2000, Provincializing Europe: Postcolonial Thought and Historical Difference, Princeton University Press, Princeton, NJ.

D'Andrade, R. 1995, 'Moral models in anthropology', Current Anthropology, vol. 36, no. 3, pp. 399-408.

Das, V. 2012, 'The dreamed guru: The entangled lives of the amil and the anthropologist', in Copeman, J. \& Ikegame, A. (eds), The Guru in South Asia: New Interdisciplinary Perspectives, Routledge, London, pp. 133-155.

Dumont, L. 1970, Homo Hierarchicus: The Caste System and Its Implications, The University of Chicago Press, Chicago.

Flueckiger, J.B. 2006, In Amma's Healing Room: Gender and Vernacular Islam in South India, Indiana University Press, Bloomington, IN.

Frøystad, K. 2005, Blended Boundaries: Caste, Class, and Shifting Faces of 'Hinduness' in a North Indian City, Oxford University Press, New Delhi.

Frøystad, K. 2009, 'Communal riots in India as a transitory form of political violence: Three approaches’, Ethnic and Racial Studies, vol. 32, no. 3, pp. 442-459. 
Fuller, C.J. 1992, The Camphor Flame: Popular Hinduism and Society in India, Princeton University Press, . Princeton, NJ.

Ghassem-Fachandi, P. 2011, 'Religious synthesis at a Muslim shrine’, in Clark-Decés, I. (ed.) A Companion to the Anthropology of India, Wiley-Blackwell, Oxford, pp. 260-276.

Gilmartin, D. \& Lawrence, B.B. 2002, 'Introduction', in Gilmartin, D. \& Lawrence, B.B. (eds), Beyond Turk and Hindu: Rethinking Religious Identities in Islamicate South Asia, India Research Press, New Delhi, pp. 1-20.

Gombrich, R.F. \& Obeyesekere, G. 1988, Buddhism transformed : religious change in Sri Lanka, Princeton University Press, Princeton, N.J.

Granovetter, M.S. 1973, 'The strength of weak ties', American Journal of Sociology, vol. 78, no. 6, pp. 1360-1379.

Handelman, D. 2008, 'Afterword: Returning to cosmology - thoughts on the positioning of belief', Social Analysis, vol. 52, no. 1, pp. 181-195.

Hansen, T.B. 1999, The saffron wave: democracy and Hindu nationalism in modern India, Princeton University Press,Princeton, N.J.

Harrison, S. 1999, 'Identity as a scarce resource', Social Anthropology, vol. 7, no. 3, pp. 239-251. Hayden, R.M. 2002, 'Antagonistic tolerance: competitive sharing of religoius sites in South Asia and the Balkans’, Current Anthropology, vol. 43, no. 3, pp. 205-231.

Heitmeyer, C. 2011, 'Religion as practice, religion as identity: Sufi dargahs in contemporary Gujarat', South Asia: Journal of South Asian Studies, vol. 34, no. 3, pp. 485-503.

Inden, R. 2000, Imagining India, Indiana University Press, Bloomington, IN.

Lindquist, G. 2008, 'Loyalty and command: Shamans, lamas and spirits in a Siberian ritual', Social Analysis, vol. 52, no. 1, pp. 111-126.

Lipner, J. 1994, Hindus: Their Religious Beliefs and Practices, Routledge, London.

Mandair, A.-P.S. 2005, 'The emergence of modern 'Sikh theology': Reassessing the passage of ideas from Trumpp to Bhai Vir Singh’, Bulletin of the School of Oriental and African Studies, vol. 68, no. 2, pp. 253-175.

Mines, D. 2007, Fierce Gods: Inequality, Ritual, and the Politics of Dignity in a South Asian Village, , Indiana University Press, Bloomington, IN.

Mines, D.P. 2002, 'Hindu nationalism, untouchable reform, and the ritual production of a South Indian village’, American Ethnologist, vol. 29, no. 1, pp. 58-85.

Osella, C. \& Osella, F. 1999, 'Seepage of divinised power through social, spiritual and bodily boundaries: Some aspects of possession in Kerala', in Assayag, J. \& Tarabout, G. (eds), La Possession en Asie du Sud: Parole, Corps, Territoire, Collection Purushartha 21, Editions de L'École des Hautes Études en Sciences Sociales, Paris, pp. 183-210.

Putnam, R.D. \& Campbell, D.E. 2010, American Grace: How Religion Divides and Unites Us, New York, Simon \& Schuster.

Rio, K.M. \& Smedal, O.H. 2009, Hierarchy: Persistence and Transformations in Social Formations, Berghahn, New York.

Smith, D.J. 2003, Hinduism and Modernity, Oxford University Press, New York. 